\title{
Kebijakan Hukum Pidana Terhadap Anak Sebagai Pelaku Kejahatan Psikotropika Di Kepolisian Resor Magelang
}

\author{
Rendy Surya Aditama , Umar Ma'ruf ${ }^{*}$, Munsharif Abdul Chalim ${ }^{*}$ \\ * Mahasiswa Program Magister (S2) Ilmu Hukum Fakultas Hukum UNISSULA Semarang, email \\ altaira.tathya@gmail.com \\ * Dosen Fakultas Hukum UNISSULA Semarang \\ Dosen Fakultas Hukum UNISSULA Semarang
}

\begin{abstract}
ABSTRAK
Penelitian ini dilatarbelakangi tingginya kasus peredaran psikotropika yang dilakukan oleh anak. Berdasarkan UU SPPA, kasus anak yang berhadapan dengan hukum yang dapat diselesaikan dengan upaya diversi adalah kasus yang ancamannya dibawah tujuh tahun, tetapi temuan dilapangan, diketahui bahwa banyak kasus anak yang ancaman hukumannya di atas tujuh tahun diselesaikan melalui diversi. Tujuan penelitian ini adalah merumuskan kebijakan formulasi penegakan hukum pidana Polres Magelang terhadap anak sebagai pelaku kejahatan psikotropika di masa yang akan datang.

Pisau analisis dalam penelitian ini adalah teori hukum progresif, teori tujuan hukum, konsep diversi, konsep psikotropika, konsep kebijakan hukum pidana, pendekatan keadilan restoratif dan UU SPPA. Penelitian ini menggunakan metode yuridis normatif dengan metode pengumpulan data studi kepustakaan.

Hasil dari penelitian ini menunjukkan bahwa kebijakan formulasi penegakan hukum pidana Polres Magelang terhadap anak sebagai pelaku kejahatan psikotropika saat ini telah menerapkan UU No. 11 Tahun 2012 Tentang Sistem Peradilan Pidana Anak. Kebijakan formulasi penegakan hukum pidana Polres Magelang terhadap anak sebagai pelaku kejahatan psikotropika di Indonesia sudah dilakukan dengan baik, namun masih terlihat adanya pelanggaran terhadap UU No. 35 Tahun 2014 Tentang Perubahan Atas UU No. 23 Tahun 2002 Tentang Perlindungan Anak pada Pasal 64, yaitu di dalam persidangan maupun publikasi hasil persidangan dengan jelas menyebutkan nama anak dimuka umum, sehingga hal ini menyalahi peraturan dalam Pasal 64 huruf i. Kebijakan formulasi penegakan hukum pidana Polres Magelang terhadap anak sebagai pelaku kejahatan psikotropika di masa yang akan datang, dapat dilakukan dengan menerapkan perlindungan anak serta menerapkan sistem peradilan pidana anak, persidangan dilakukan setelah anak berusia dewasa, serta pelaksanaan hukuman pidana dilakukan setelah anak berusia 18 tahun. Saran terkait temuan penelitian ini adalah dapat menanggulangi tindak pidana psikotropika yang dilakukan oleh anak dengan menerapkan kebijakan formulasi penegakan hukum pidana Polres Magelang terhadap anak sebagai pelaku kejahatan psikotropika di masa yang akan datang.
\end{abstract}

Kata kunci: kebijakan, formulasi, psikotropika, anak.

\begin{abstract}
This research is motivated by high psychotropic circulation cases conducted by children. Under the SPPA Act, the case of a law-facing child who can be resolved by a diversion effort is a case that threats under seven years, but findings in the field, it is known that many cases of children whose sentence threats over seven years are resolved through a diversion. The purpose of this study is to formulate policy formulation of criminal law enforcement Polres Magelang against children as perpetrators of psychotropic crime in the future.
\end{abstract}


The analysis blade in this research is progressive law theory, theory of law objective, diversion concept, psychotropic concept, concept of criminal law policy, restorative justice approach and SPPA law. This research uses normative juridical method with data collection method of literature study.

The results of this study indicate that policy formulation of criminal law enforcement Polres Magelang to child as perpetrator of psychotropic crime at this time have applied Law no. 11 Year 2012 on the Criminal Justice System of Children. Policy formulation of criminal law enforcement of Magelang Police against child as perpetrator of psychotropic crime in Indonesia has been done well, but still seen violation against Law no. 35 Year 2014 About Amendment to Law no. Law No. 23 Year 2002 on Child Protection in Article 64, namely in the hearing and publication of the proceedings clearly states the name of the child in public, so that this is contrary to the rules in Article 64 letter $\mathrm{i}$. The policy of formulation of criminal law enforcement of Magelang Police against child as perpetrator of psychotropic crime in the future can be done by applying child protection as well as applying the child criminal justice system, the trial is done after the adult child, and the implementation of criminal punishment is done after the child is 18 years old. Suggestions related to the findings of this study is to cope with psychotropic crimes committed by children by applying the policy of criminal law enforcement formulation Magelang Police against children as perpetrators of psychotropic crimes in the future.

Keywords: policy, formulation, psychotropic, child.

\section{PENDAHULUAN}

Peredaran gelap narkotika dan psikotropika menjamur di Indonesia disebabkan oleh banyaknya pintu masuk yang tersedia di berbagai wilayah perbatasan Indonesia, lemahnya pengawasan di daerah perbatasan, murahnya harga kurir pengedar narkotika dan psikotropika, mudahnya perekrutan kurir pengedar narkotika dan psikotropika, tingginya jumlah penduduk, mudahnya mencari tempat tinggal bagi pelaku pengedar narkotika dan psikotropika serta adanya kondisi penerapan sanksi dan kepastian hukum yang kurang maksimal ${ }^{1}$.

Dampak peredaran narkotika dan psikotropika tersebut adalah banyaknya penyalahgunaan narkoba di Indonesia, khususnya yang terjadi di kalangan remaja. Hal ini dibuktikan dengan ditemukannya 42 Pelajar yang mengkonsumsi psikotropika di wilayah hukum Polres Magelang pada tanggal 13 September 2017 lalu. Hal ini terjadi karena penindakan terhadap penyalahgunaan psikotropika tersebut menimbulkan pro-kontra, sehingga hal ini dapat mengkodisikan bahwa peredaran psikotropika di Indonesia ini masih bebas di pasaran, dan sering disalahgunakan bagi sebagian orang ${ }^{2}$. Oleh karena itu diperlukan tindakan tegas kepada para pelaku penyalahgunaan psikotropika, sebagaimana yang telah diatur dalam Undang-Undang Nomor 5 Tahun 1997 tentang Psikotropika.

Berdasarkan hasil temuan selanjutnya diketahui bahwa para prekusor psikotropika ini mulai mengincar anak. Dengan melihat sisi psikologi anak yang belum memahami aspek hukum serta sikap secara dewasa, mereka juga memanfaatkan celah hukum pada Undang-Undang Nomor 11 Tahun 2012 tentang Sistem Peradilan Pidana Anak, yang menganjurkan bahwa tindak pidana yang dilakukan oleh anak terlebih dulu diupayakan diversi. Dengan adanya pertimbangan inilah kemungkinan prekusor tersebut memilih anak sebagai pengedar psikotropika. Opini tersebut juga diperkuat dengan

\footnotetext{
${ }^{1}$ Siswandi. 2011. Pangsa Narkotika Dunia Indonesia. Jakarta: Gramedia. HIm. 16.

${ }^{2}$ Hanz Jimenez Salim. 2017. Kapolri: Penyalahgunaan Psikotropika Masih Dianggap Biasa. Liputan 6. Diakses dalam News.liputan6.com/read/3059214/kapolri-penyalahgunaan-psikotropika-masih-dianggap-biasa, 29 November 2017.
} 
adanya temuan pengedar anak pada tahun 2011 hingga 2014 meningkat hampir $300 \%{ }^{3}$.

Secara yuridis, anak yang mengedarkan psikortropika dapat dikategorikan sebagai pelaku tindak pidana psikotropika. Namun jika memandang sisi psikologi anak, kondisi anak yang demikian, anak juga dapat dinilai sebagai korban (crime without victim) ${ }^{4}$. Berdasarkan penjelasan tersebut, maka anak sebagai pelaku kejahatan psikotropika tidak boleh dipandang pada satu sisi saja, tetapi persepsi tentang psikologi anak dan perilakunya juga harus dipertimbangkan dengan matang, yang sangat memungkinkan bahwa anak tersebut lebih cenderung menjadi korban suatu tindak pidana peredaran psikotropika. Berdasarkan sudut pandang ini maka anak harus diberi perlakuan yang berbeda, antara pelaku tindak pidana dan korban dari terjadinya tindak pidana. Hal ini perlu dilakukan karena anak adalah generasi penerus bangsa yang sudah seharusnya memperoleh perlindungan, sebagaimana pada anak yang terlibat dalam suatu tindakan kejahatan dan menyebabkan anak berkonflik dengan hukum, anak yang berhadapan dengan hukum atau anak berada pada situasi yang khusus. ${ }^{5}$ Melihat potensi anak tersebut, maka sangat dibutuhkan upaya perlindungan terhadap anak tersebut yang terlibat sebagai pelaku kejahatan psikotropika, baik pada tataran Nasional maupun Internasional.

Melihat dinamika hukum yang ada pada Undang-Undang Nomor 5 Tahun 1997 Tentang Psikotropika dengan Undang-Undang Nomor 11 Tahun 2012 Tentang Sistem Peradilan Pidana Anak, hal ini menjadi problematika tersendiri bagi para penegak hukum dalam menentukan langkah penanganan tindak pidana psikotropika yang dilakukan oleh anak tersebut. Sehingga pelanggaran tindak pidana peredaran maupun penyalahgunaan psikotropika yang dilakukan oleh anak ini akan mampu menempatkan negara berada pada masalah yang sangat serius.

Seorang penegak hukum dalam melakukan prosedur hukum kepada sanksi anak yang berhadapan dengan hukum atau dalam situasi yang khusus ini, harus menggunakan paradigma yang khusus. Hal ini sangat perlu dilakukan karena sanksi yang diberikan harus mampu memberikan nilai edukasi, dan sifat sanksi tersebut harus sesuai dengan makna filosofi. Oleh karena itu, sanksi tersebut harus memberikan jalan keluar terbaik dari permasalahan yang ada, dan demi kepentingan terbaik bagi anak, yang sesuai dengan azas ultimum remidium. Namun pada sisi yang berbeda, pemberian sanksi kepada anak sebagai pelaku pengedar psikotropika tersebut yang diarahkan pada tujuan sistem hukum Indonesia pada sudut pandang tujuan hukum yang memberikan efek jera, dan bentuk dari ketidaksetujuan dari tindakan yang dilakukan oleh anak tersebut, maka hal ini akan menjadi dilema tersendiri bagi para penegak hukum. Berdasarkan kondisi inilah selanjutnya diperlukan rumusan kebijakan hukum pidana terhadap anak sebagai pelaku tindak pidana psikotropika agar dinamika kejahatan psikotropika yang dilakukan oleh anak dapat diselesaikan sesuai dengan tujuan hukum yang ada di Indonesia.

\section{Metode Penelitian}

Pendekatan penelitian yang digunakan penulis dalam melakukan penelitian ini adalah yuridis normatif. Pendekatan yuridis normatif adalah penelitian yang dilakukan dengan cara menghimpun data penelitian melalui studi dokumen atau studi kepustakaan yang dipergunakan untuk memecahkan

\footnotetext{
${ }^{3}$ David Setyawan. 2015. KPAl: Jumlah Pengedar Narkoba Anak Meningkat Hingga 300 Persen. KPAI. Diakses dalam http://www.kpai.go.id/berita/kpai-jumlah-pengedar-narkoba-anak-meningkat-hingga-300-persen/. 29 November 2017.

${ }^{4}$ Koesno Adi. 2014. Diversi Tindak Pidana Narkotika Anak. Malang: Setara Press. HIm. 135.

${ }^{5}$ Pasal 37, Pasal 39 dan Pasal 40 Konvensi Hak Anak.
} 
masalah penelitian ${ }^{6}$. Pendekatan yuridis normatif ini dipilih karena dengan menggunakan metode tersebut dalam penelitian hukum ini peneliti akan mampu menemukan kebenaran dengan menggunakan metode induktif dan kriterium untuk pengukuran sebuah fakta di lapangan. Sehingga hasil pengumpulan data yang diperoleh melalui studi dokumen atau studi kepustakaan ini dapat digunakan untuk menjelaskan asumsi-asumsi yang ada, untuk dipergunakan dalam menjawab serta menjelaskan permasalahan yang ada dalam penelitian ini, sesuai dengan fakta yang ada di lapangan.

Jenis dan sumber data dalam penelitian ini berasal dari data sekunder. Jenis dan sumber data ini merupakan salah satu unsur yang cukup penting, karena kualitas informasi atau data yang akan dianalisis sangat bergantung kepada sumber kepustakaan yang memberikan informasi terkait dengan permasalahan penelitian ini. Sumber data seperti yang diungkapkan, ditujukan untuk mendapatkan data. Terdapat bermacam-macam data yang dapat dikumpulkan oleh peneliti. Jenis dan sumber data dalam penelitian ini diperoleh peneliti dengan cara Peneliti akan terjun ke lapangan itu sendiri, dengan cara melakukan pengumpulan data, analisis dan membuat kesimpulan.

Jenis dan sumber data dalam penelitian ini adalah hasil penelusuran terhadap dokumendokumen maupun laporan-laporan usulan gelar perkara, SP3, hasil notulen dan sumber tertulis lainnya terkait permasalahan pertimbangan penyidik dalam penerapan diversi pada kasus-kasus anak yang berhadapan dengan hukum khususnya terkait dengan kejahatan psikotropika pada Satuan Reskrim Polres Magelang dan sumber tertulis lainnya terkait permasalahan dalam penelitian ini.

Sumber data yang dibutuhkan berupa :

a. Bahan Hukum Primer yaitu bahan-bahan yang bersumber dari peraturan perundang-undangan yang ada kaitannya dengan psikotropika dengan pelaku anak serta sistem peradilan pidana anak yaitu :

1) UUD 1945

2) Undang-Undang Nomor 4 Tahun 1979 tentang Kesejahteraan Anak,

3) UU No. 5 Tahun 1997 tentang Psikotropika,

4) Undang-undang Nomor 2 Tahun 2002 Tentang Kepolisian Negara Republik Indonesia

5) Undang-Undang Nomor 23 Tahun 2002 tentang Perlindungan Anak,

6) Undang-undang Nomor 11 Tahun 2012 tentang Sistem Peradilan Pidana Anak

7) KUHP

b. Bahan Hukum Tersier yaitu berupa kamus-kamus yang ada kaitannya dengan sistem peradilan pidana anak yaitu Kamus Besar Bahasa Indonesia dan Kamus Hukum.

\section{HASIL PENELITIAN DAN PEMBAHASAN}

Hasil penelitian ini dijelaskan pada sub bab-sub bab berikut ini:

\section{Kebijakan hukum pidana yang diterapkan oleh Polres Magelang terhadap anak sebagai pelaku kejahatan psikotropika}

Berdasarkan Pasal 8 Undang-undang Nomor 11 Tahun 2012 Tentang Sistem Peradilan Pidana Anak di atas, dapat diketahui bahwa proses pelaksanaan penyidikan terhadap pelaku anak dilakukan dengan cara diversi dengan menggunakan pendekatan Keadilan Restoratif. Pada proses diversi ini wajib memperhatikan kesejahteraan dan tanggung jawab Anak, penghindaran stigma negatif, menjaga kepatutan, dan ketertiban umum.

\footnotetext{
${ }^{6}$ Soerjono Soekanto dan Sri Mamudji. 1985. Penelitian Hukum Normatif Suatu Tinjauan Singkat. Jakarta: Rajawali Pers. HIm. 52.
} 
Berdasarkan penjelasan pada KUHP, UU No 11 Tahun 2012 tentang Sistem Peradilan Pidana Anak dan UU No 35 Tahun 2014 tentang Perlindungan Anak, dapat dijelaskan sebagai berdasarkan ketiga sumber hukum positif di Indonesia, diketahui bahwa penyelesaian kasus anak yang berhadapan dengan hukum dilaksanakan melalui diversi. Sedangkan dalam Undang-Undang Nomor 5 Tahun 1997 tentang Psikotropika, diketahui bahwa Polri wajib melakukan pencegahanpelibatan anak yang belum berumur 18 (delapan belas) tahun dalam kegiatan penyalahgunaan dan/atau peredaran gelap psikotropika. Sedangkan ancaman dari pelaku sebagai pengedar psikotropika tersebut adalah mendapatkan ancaman selama 20 tahun dan pidana denda 750.000.000,00. Dari pernyataan tersebut diketahui tidak ada pembedaan besarnya hukuman yang diberikan oleh pelaku yang dilakukan oleh orang dewasa, maupun oleh pelaku seorang anak. Sedangkan menurut UU No 11 tahun 2012 tentang Sistem Peradilan Pidana Anak, diketahui bahwa pelaku pengerdaran psikotropika ini mendapat ancaman hukuman 20 tahun. Sedangkan menurut UU No 35 Tahun 2014 tentang Perlindungan Anak, penahanan dapat dilakukan sebagai uaya terahir dan dengan waktu yang paling singkat.

Berdasarkan peraturan hukum positif di Indonesia tersebut, maka dapat diketahui bahwa terdapat hubungan yang saling mendukung dalam memberikan pelindungan hukum bagi anak yang bermasalah dengan hukum. Pemberian hukuman tersebut merupakan upaya terahir dari penanggulangan tindak pidana psikotropika yang dapat dilakukan oleh penegak hukum saat ini, sedangkan penanggulangan awal yang dapat digunakan untuk mengatasi masalah tindak pidana psikotropika dengan pelaku anak dapat dilakukan dengan upaya diversi. Upaya diversi ini diatur dalam Undang-undang Nomor 11 Tahun 2012 Tentang Sistem Peradilan Pidana Anak, yang dalam Pasal 1, yaitu penanganan anak yang berhadapan dengan hukum dengan pelaksanaan diversi atau pengalihan penyelesaian perkara anak dari proses peradilan pidana ke proses diluar peradilan pidana yang tertuang pada Undang-undang Negara Republik Indonesia Nomor 11 tahun 2012 Pasal 5 ayat (3) selanjutnya disebut sistem peradilan pidana anak, yang menegaskan dalam sistem peradilan pidana anak wajib diupayakan diversi. Diversi berkaitan erat dengan perlindungan Hak Asasi Manusia karena di sisi pelaku, mediasi penal memberikan kesempatan kepada pelaku untuk memperbaiki diri, mengakui perbuatan dan bertanggung jawab atas apa yang ia lakukan. Kebijakan pelaksanaan (Applicative Policy) mediasi hukum meliputi mediasi hukum di luar proses peradilan pidana (Law Mediation Out of Criminal Justice Process), dan mediasi hukum didalam proses peradilan pidana (Law Mediation Within Criminal Justice System) yang meliputi fungsi mediasi pada tahap penyidikan, penuntutan, pemeriksaan di muka pengadilan.

\section{Kebijakan hukum pidana yang diterapkan oleh Polres Magelang terhadap anak sebagai pelaku kejahatan psikotropika yang akan datang}

Kebijakan formulasi hukum pidana dalam rangka penanggulangan tindak pidana anak sebagai pelaku kejahatan psikotropika di masa yang akan datang dapat disusun dari hasil perbandingan Rancangan Undang-Undang atau Undang-Undang Sistem Peradilan Pidana Anak yang ada di Indonesia dengan Undang-Undang Peradilan Anak di Luar Negeri.

Upaya penyelesaian perkara diluar pengadilan yang berdasarkan jenis tindak pidana pada tindak pidana anak sebagai pelaku kejahatan psikotropika, baik di negara Indonesia maupun di negara Belanda, upaya penyelesaian perkara diluar pengadilan atau disversi tidak bisa dilakukan di negara Indonesia maupun di negara Belanda. Sedangkan berbeda dengan upaya penyelesaian perkara diluar pengadilan yang didasarkan pada kewenangan penegak hukum, dapat diketahui bahwa di Indonesia Penegak Hukum/ Polisi memiliki kewenangan untuk menghentikan penyidikannya karena adanya Diskresi Kepolisian sebagai jalan untuk menyelesaikan penyelesaian perkara di luar pengadilan, yaitu untuk menanggulangi kasus anak sebagai pelaku kejahatan psikotropika. Diversi dapat dilakukan 
karena memandang usia anak masih berumur di bawah 18 tahun. Begitupula dengan hukum di negara Belanda yang menyatakan bahwa penyelesaian perkara diluar pengadilan berdasarkan kewenangan aparat penegak hukum dapat dilakukan jika memandang usia pelaku yang masih anak-anak.

Melihat Rancangan Undang-Undang, Indonesia juga menerapkan penyelesaian perkara di luar pengadilan (afdoening buiten proces). Hal ini sesuai dengan asas peradilan cepat, biaya murah dan sederhana. Penyelesaian di luar pengadilan tercantum di dalam Pasal 42 ayat (2) dan (3) Rancangan. Pasal 42 ayat (2) RUU KUHAP berbunyi: "Penuntut umum juga berwenang demi kepentingan umum dan/atau alasan tertentu menghentikan penuntutan baik dengan syarat maupun tanpa syarat." Sedangkan pada Pasal 42 ayat (3) RUU KUHAP juga menyebut syarat-syarat itu sebagai berikut:

1. Tindak pidana yang dilakukan bersifat ringan;

2. Tindak pidana yang dilakukan diancam dengan pidana penjara paling lama 4 tahun;

3. Tindak pidana yang dilakukan hanya diancam dengan pidana denda;

4. Umur tersangka pada waktu melakukan tindak pidana di atas tujuh puluh tahun; dan/atau

5. Kerugian sudah diganti.

Berdasarkan penjelasan Rancangan Undang-Undang ini juga diketahui bahwa penanggulangan kasus anak sebagai pelaku kejahatan psikotropika diluar pengadilan tidak dapat diterapkan upaya diversi karena ancaman hukumannya 20 tahun, dilakukan upaya disversi tersebut dapat dilakukan untuk menyelesaikan kasus tersebut.

Berdasarkan perbandingan hukum pidana anak di Indonesia, di Belanda dan RUU KUHAP di Indonesia yang dijelaskan di atas, dapat diketahui bahwa kebijakan yang diambil oleh negara Indonesia dengan negara Belanda memiliki kesamaan dalam menyelesaikan kasus diluar pengadilan yang dilihat dari kewenangan penegak hukum ataupun penyelesaian kasus diluar pengadilan berdasarkan jenis tindak pidana maupun berdasarkan kewenangan aparat penegak hukum. Persamaan dari kedua kebijakan tersebut adalah penyesaian kasus tindak pidana anak sebagai pelaku kejahatan psikotropika diluar pengadilan tidak bisa dilakukan. Namun mengingat pelaku anak sebagai pelaku kejahatan psikotropika tersebut adalah seorang anak yang belum memiliki kematangan secara psikologis, penyelesaian perkara kasus anak sebagai pelaku kejahatan psikotropika yang dilakukan oleh anak dapat dilakukan diluar pengadilan (disversi). Dari hasil pembahasan tersebut selanjutnya dapat digunakan untuk membuat kebijakan formulasi untuk menanggulangi tindak pidana anak sebagai pelaku kejahatan psikotropika yaitu tetap memberikan perlindungan anak dan menerapkan sistem peradilan pidana anak, melakukan persidangan setelah anak berusia 18 tahun atau dewasa dan menerapkan hukum pidana bagi anak, tetapi pelaksanaan pemidanaannya dilakukan setelah anak berusia 18 tahun.

\section{PENUTUP}

\section{Simpulan}

Berdasarkan hasil pembahsan di atas, dapat disimpulkan bahwa :

1. Kebijakan formulasi dalam rangka penanggulangan tindak pidana anak sebagai pelaku kejahatan psikotropika saat ini adalah menerapkan KUHP Pasal 289 sebagaimana ancaman hukuman pidana yang diberikan kepada tersangka anak tersebut yang ada di dalamnya, melakukan upaya Diversi dengan pendekatan restorasi sebagaimana yang termuat dalam Undang-undang Nomor 11 Tahun 2012 Tentang Sistem Peradilan Pidana Anak sehingga pemidanaan atau perampasan hak kemerdekaan anak dapat diupayakan terlebih dahulu, meskipun upaya diversi selanjutnya tidak memberikan hasil yang positif, serta menerapkan Undang-undang Nomor 35 Tahun 2014 Tentang 
Perubahan Atas Undang-undang Nomor 23 Tahun 2002 Tentang Perlindungan Anak pada Pasal 64 guna memberikan perlindungan terhadap hak-hak anak seperti anak yang dijatuhi hukuman pidana, anak ditempatkan dalam penjara khusus anak atau dititipkan di LPKS, atau badan pengawasan sosial, memberikan pendidikan yang layak dan lain sebagainya sebagaimana yang termuat dalam undang-undang perlindungan anak tersebut.

2. Kebijakan formulasi hukum pidana dalam rangka penanggulangan tindak pidana anak sebagai pelaku kejahatan psikotropika di masa yang akan datang, dapat dilakukan dengan menggunakan hasil perbandingan dari hukum pidana antara negara Belanda dan Indonesia serta RUU KUHAP Indonesia, yang menghasilkan kebijakan sebagai berikut: memberikan perlindungan anak dan menerapkan sistem peradilan pidana anak, melakukan persidangan setelah anak berusia 18 tahun atau dewasa dan menerapkan hukum pidana bagi anak, tetapi pelaksanaan pemidanaannya dilakukan setelah anak berusia 18 tahun.

\section{Saran}

Sehubungan dengan hasil temuan penelitian dan pembahasan, saran yang dapat disampaikan penulis terkait penanggulangan tindak pidana anak sebagai pelaku kejahatan psikotropika adalah:

1. Menanggulangi tindak pidana anak sebagai pelaku kejahatan psikotropika dengan menerapkan sistem peradilan pidana anak dan menerapkan perlindungan anak serta menerapkan kebijakan formulasi hukum pidana dalam rangka penanggulangan tindak pidana penanggulangan tindak pidana anak sebagai pelaku kejahatan psikotropika di masa yang akan datang.

2. Menerapkan kebijakan kepada pelaku anak atas tindak pidana psikotropika dengan memperhatikan motif dilakukannya tindak pidana tersebut, sehingga dari pengetahuan adanya motif tersebut dapat diketahui permasalahan penyebabnya, sehingga dapi pengetahuan tersebut dapat diberikan pembimbingan kepada orangtua secara khusus bagi orang tua pelaku serta orangtua pada umumnya agar memberikan edukasi dan perlindungan kepada anak dari bahaya psikotropika.

3. Bekerjasama dengan dinas pendidikan agar dinas pendidikan memberikan penyuluhan kepada para siswa mengenai nakoba khususnya bahaya psikotropika sejak dini serta memberikan pendidikan keagamanan, serta pendidikan moral dan pancasila agar anak memiliki benteng yang kuat dalam menanggapi perkembangan IPTEK yang ada saat ini agar anak tidak melakukan perbuatan yang melanggar hukum.

\section{DAFTAR PUSTAKA}

Siswandi. 2011. Pangsa Narkotika Dunia Indonesia. Jakarta: Gramedia.

Hanz Jimenez Salim. 2017. Kapolri: Penyalahgunaan Psikotropika Masih Dianggap Biasa. Liputan 6. Diakses dalam News.liputan6.com/read/3059214/kapolri-penyalahgunaan-psikotropika-masihdianggap-biasa, 29 November 2017.

David Setyawan. 2015. KPAI: Jumlah Pengedar Narkoba Anak Meningkat Hingga 300 Persen. KPAl. Diakses dalam http://www.kpai.go.id/berita/kpai-jumlah-pengedar-narkoba-anak-meningkathingga-300-persen/. 29 November 2017.

Koesno Adi. 2014. Diversi Tindak Pidana Narkotika Anak. Malang: Setara Press.

Pasal 37, Pasal 39 dan Pasal 40 Konvensi Hak Anak.

Satjipto Rahardjo. 2009. Hukum Progresif: Sebuah Sintesa Hukum Indonesia. Yogyakarta: Genta Publishing. 
Jurnal Daulat Hukum Volume 1 No. 1 Maret 2018 : 117 - 124

Otje Salman dan Anthon F. Susanto. 2013. Teori Hukum. Bandung: Refika Aditama.

Sudikno Mertokusumo. 2010. Mengenal Hukum. Yogyakarta: Universitas Atma Jaya Yogyakarta.

Achmad Ali. 2009. Teori Hukum (Legal Theory) dan Teori Peradilan (Judicialprudence). Jakarta: Kencana Prenada Media Group.

Soerjono Soekanto dan Sri Mamudji. 1985. Penelitian Hukum Normatif Suatu Tinjauan Singkat. Jakarta: Rajawali Pers. 